\title{
Influence of Microwave Irradiations on Germination, Seedling Growth and Electrolyte Leakage of Barley (Hordeum vulgare $\mathrm{L}$.)
}

\author{
Abdelghafar M. Abu-Elsaoud ${ }^{1 *}$ and Sameer H. Qari ${ }^{2}$ \\ ${ }^{1}$ Department of Botany, Faculty of Science, Suez Canal University, Ismailia, Egypt \\ ${ }^{2}$ Department of Biology, Aljamom university college, Umm Al-Qura University, Saudi Arabia
}

\begin{abstract}
The introduction of telecommunication instruments, especially microwave, leads to a massive increase in electromagnetic pollution. The current research intends to assess the physiological effects of microwave radiations on barley (Hordeum vulgare L.). Barley seeds were exposed to eight different exposure periods of microwave from 0 to 600 seconds. Germination parameters were dose-dependents, the percentage of germinated seeds increased after short exposure periods to microwave recording $100 \%$ germination. Further the germination rate, relative germination coefficient were also increased after short exposure periods to microwave. Longer exposure periods reduced the percentage of germination, germination rates, and various germination indices. Morphological and growth traits showed a similar trend and were significantly decreased after longer exposure periods to microwave. Chlorophyll contents were significantly decreased with increasing exposure periods of microwave. Microwave-induced electrolyte leakage $(\%)$ was significantly increased $\left(\mathrm{r}=0.92^{*}, p<0.001\right)$ following pretreatment with different exposure periods of microwave. Current research data gives spotlight on possible positive and negative effects of microwave on barley and recommended to minimize the exposure time to environmental microwave to safeguard recovering ability of biological systems. However, the positive effects of microwave are of considerable importance for improving crops.
\end{abstract}

Keywords: Agricultural practices, Coleopterans, Ground fauna, Habitats, Hymenoptera, Macro invertebrates, Urbanization, Pitfall traps, Suez Canal region.

\section{INTRODUCTION}

The Development of life was influenced by two ubiquitous forces; the gravity and electromagnetism, the two forces expected to have essential role in the functional activities of biological systems and organisms (Balmori, 2009). A massive increase in electromagnetic pollution since the introduction of telecommunication instruments in the 1990's led to increased exposure to radio and microwave frequency fields (Ragha et al., 2011). These electromagnetic fields can have a deleterious and damaging effects depending on the exposure doses, power level, frequencies, pulsed or continuous wave and the dielectric properties of exposed tissue (Banik et al., 2003). Microwave are a part of electromagnetic radiations spectrum comprising frequencies ranging from $300 \mathrm{MHz}$ to $300 \mathrm{GHz}$, further, it acts through absorption on molecular level manifesting as vibrational energy or heat and a biological effects (Pakhomov et al., 1998). Relevant research suggests that microwaves may have long-term health effects (Lin, 2004). Identification, evaluation and assessment of the bio-effects of microwaves have been complex and controversial, because of the absence of a clear mechanism of the impact of microwave radiofrequencies and biological systems, there has been a persistent view in biophysical and engineering sciences, that microwave fields are incapable of inducing bioeffects other than by heating (Banik et al., 2003).

In recent times, non-thermal bio-effects of microwaves on tissue responses were being acknowledged (Banik et al., 2003). Various research data have offered convincing evidence of non-thermal microwave effects and have also indicated various consistencies in these influences including: dependence of frequency, polarization, modulation and intensity, wavelength, duration of irradiation, radiation exposure dose representing a long-term cumulative influence (Kemerov et al., 1999; Kositsky et al., 2001; Belyaev, 2005; Lai, 2005; AbuElsaoud, 2015; Williams, 2016).

Microwave irradiation could affect plant growth, development and seed germination (Ragha et al., 2011; Radzevičius et al., 2013; Abu-Elsaoud, 2015). Low intensity microwave were reported not to affect the plant growth and development but the increased irradiation doses of microwave has decreased and slowed seed germination (Oprica, 2008). The direct effects of microwave on germination of cereals were studied by Ponomarev et al. (1996) where, a wavelength $\lambda=1 \mathrm{~cm}$ and irradiation exposure dose of up to 40 minutes were applied to barley, oats, and wheat seeds leading to improved germination rate with optimum effect after 20 minutes of microwave exposure (Ponomarev et al., 1996). A study of irradiating vegetable seeds with high power microwave radiations reported a stimulation influence of various germination and growth rate parameters by microwave (Radzevičius et al., 2013).

The effect of microwave irradiation with a different power on various seed germination consequences of four different ornamental crop species has been studied by Aladjadjiyan (2002) where, increase in various germination consequences were observed. A comparative effect of microwave radiations on germination and growth of six different Egyptian genotypes were asse-

* Corresponding author: abdoacacia@gmail.com 
ssed using different exposure times, Abu-Elsaoud (2015) supported a dose dependent possible stimulation effect of microwave on growth and germination. Crețescu et al. (2013) studied the effect of microwave radiations of $2.45 \mathrm{GHz}$ after exposure to 0,10 , and 20 seconds on the chlorophyll contents of four barley genotypes, results revealed that a dose-dependent change in chlorophyll contents was observed ranging from reduction of chlorophyll in sensitive genotypes to increases in tolerant ones (Crețescu et al., 2013). Microwave irradiations induce resonant phenomena within biological system and have a stimulatory effect on biological organisms (Aladjadjiyan, 2002). Most microwave irradiation studies focused on possible biological effects from phone masts and microwave radiofrequencies on animal and human health (Hutter et al., 2006; Balmori, 2009). The biochemical mechanism by which microwave radiations affect biological systems of living organisms is not fully comprehended and the mechanism could vary according to the amplitude, frequency and the irradiation duty cycle (Monteiro et al., 2008; Aladjadjiyan, 2010; Abu-Elsaoud, 2015; Williams, 2016). The present study was conducted to study the effect of seed irradiation with different doses of microwave radiations on the membrane electrolyte leakage, germination and growth of Egyptian barley Hordeum vulgare L seedlings.

\section{MATERIALS AND METHODS}

\section{Plant materials}

Seeds of selected Barely (Hordeum vulgare L.) genotype Giza-129 were acquired from Agricultural Research Station at Ismailia and Agricultural Research Centre (ARC), Giza, Egypt in the months of NovemberDecember, 2016. The cereal lot of seeds was cleaned removing unwanted matter and damaged seeds, all seeds were surface sterilised by immersion in freshly prepared $10 \%$ sodium hypochlorite $(\mathrm{NaOCl})$ for 2 minutes prior to use.

\section{Microwave irradiation treatment}

Microwave irradiation were carried out using a Magnetron with frequency of $2.45 \mathrm{GHz}$, wavelength of $12 \mathrm{~cm}$, a maximum output power of $800 \mathrm{~W}$, maximum intensity were estimated to be $51.5 \mathrm{~kW} . \mathrm{m}^{-3}$ by dividing the output power to the working volume $\mathrm{m}^{-3}$. Experimental details were presented in figure (1). Seeds were first soaked in distilled water for 1 hour as recommended by Aladjadjian and Svetleva (1997) to enhance the absorption of microwave energy. Seeds of selected barley genotype (Hordeum vulgare) cv. Giza-129 were divided into eight groups, each group containing 30 seeds of (three replicas of ten seeds). The first group represents the untreated control and remaining seven groups were irradiated with different exposure periods to microwave $(1,5,10,30,60,300$ and 600 seconds).

\section{Growth conditions}

Seeds of the eight barley groups (untreated and treated with microwave radiations) were transferred to a $12 \mathrm{~cm}$ diameter $10 \mathrm{~cm}$ height plastic pots 10 -seeds were sown per pot. Pots were filled with hydrogel, which is a good absorbent of macromolecule compound that can effectively bind water that is very important in case of seedlings growing in unfavourable drought conditions (Boczoń et al., 2009; Mazen et al., 2015). Pots were maintained in a controlled growth room at $25^{\circ} \mathrm{C}\left( \pm 2^{\circ} \mathrm{C}\right)$, $14 \mathrm{~h}$ daylength, and $200 \pm 5 \mu$ mole. $\mathrm{m}^{-2} . \mathrm{S}^{-1}$ PPFD (Photosynthetic Photon Flux Density).

\section{Effect of microwave radiations on germination}

Various germination traits were estimated and monitored during the experiment at different time-points; 3 , 5, 7, 9 and 12 days after sowing (DAS). Based on the obtained results, the percentage of germinated seeds $\mathrm{N}_{\mathrm{k}}$, germination rate $S_{k}$ (seed. $h^{-1}$ ), maximum number of germinated seeds $\left(\mathrm{n}_{\max }\right)$, relative germination coefficient $\left(W_{k}\right)$ were calculated with the using germination formulas by Ciupak et al. (2007) presented in table (1).

\section{Effect of microwave radiations on growth}

Shoot and root biomass were determined for Hordeum vulgare L. plants irradiated with $2.45 \mathrm{GHz}$ radiofrequency and the untreated control. Biomass allocation within plants was calculated in $\mathrm{g}$ per $\mathrm{g}$ (shoot /root ratio, $\mathrm{g} . \mathrm{g}^{-1}$ ) of total seedling biomass to avoid size effects, and calculated as a mean of three replicas. Data of Biomass allocation and shoot-to-root ratios were assessed statistically in plants irradiated with microwave radiofrequency versus the control ones to evaluate the change in biomass allocation pattern.

\section{Quantification of leaked ions}

Electrolyte leakage technique was used to evaluate cell membrane stability after seed exposure to microwave radiations. Leaves of Hordeum vulgare L. were collected from both microwave-treated and untreated plants. The leaves were cleaned, washed in tap water then weighed and rinsed 3 times for 2-3 minutes in deionised water to remove the dusts and electrolytes adhering to the surfaces and lightly cleaned with tissue papers. Leaf discs of $0.5 \mathrm{~cm}^{2}$ were subsequently floated in $10 \mathrm{~mL}$ of deionised water. Electrolyte leakage in the solution was determined after $22 \mathrm{~h}$ at room temperature using Chemitrix type 700 portable conductivity meters according to method described by Campos et al. (2003).

\section{Chlorophyll content}

Leaf chlorophyll contents were estimated by using the LEAF+ by FT Green LLC. (Wilmington, USA). Portable chlorophyll meter is a non-destructive, handheld portable sensor that estimates chlorophyll content of leaves (Novichonok et al., 2016). The device can measure leaves that are up to 0.1 in $(2.5 \mathrm{~mm})$ in thick- 
ness. Two LEDs emit light from the upper part of the aperture at two wavelengths, $660 \mathrm{~nm}$ and $940 \mathrm{~nm}$. Chlo- rophyll meter estimate chlorophyll contents in relative units the chlorophyll index (Novichonok et al., 2016).

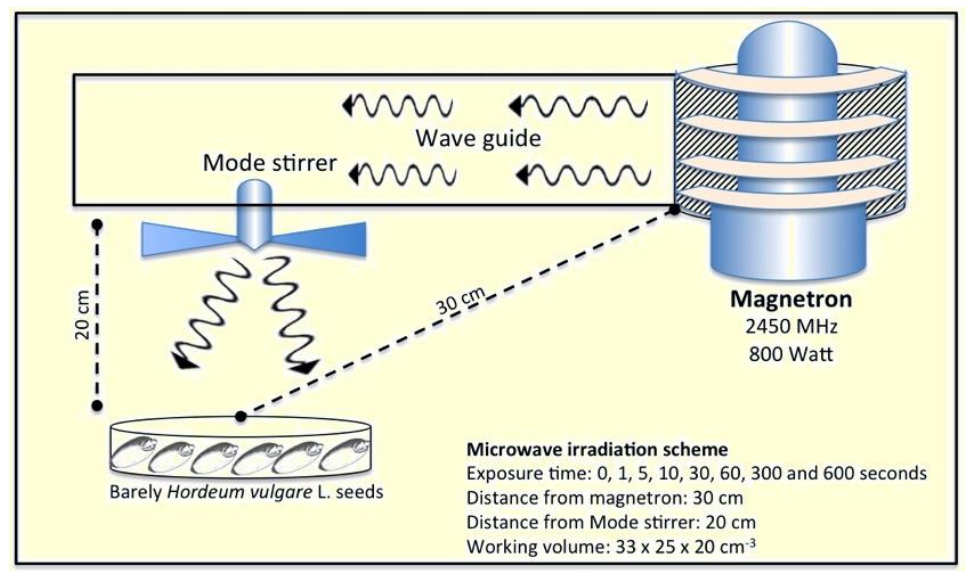

Figure (1): Microwave irradiation Scheme and experimental conditions including magnetron, exposure doses, radiation density and output power.

Table (1): Germination formulas and time points of various estimated germination traits of barley under the effect of microwave.

\begin{tabular}{|c|c|c|c|}
\hline Germination parameter & Formula & $\begin{array}{l}\text { Time } \\
\text { points } \\
\text { (days) }\end{array}$ & Reference \\
\hline Percentage of Germinated seeds (\%) & $\begin{array}{l}\qquad N_{k}=\frac{n_{k}}{n_{c}} x 100 \\
\text { Where: } \\
n_{k} \text { - number of germinated seeds, } \\
n_{c} \text { - total number of sown seeds }\end{array}$ & $\begin{array}{l}3,5,7,9 \\
12\end{array}$ & (Ciupak et al., 2007) \\
\hline Number of germinated seeds $N_{k}$ & Number of germinated seeds & $\begin{array}{l}3,5,7,9 \\
12\end{array}$ & (Ciupak et al., 2007) \\
\hline Germination rate $S_{k}$ & $\begin{array}{l}\qquad S_{k}=\frac{n_{\max }}{\Delta t} \\
\text { Where: } \\
n_{\max }-\text { maximum number of germinated seeds recorded } \\
\text { during the count, } \\
\Delta t \text { time interval between two successive counts } \\
n(t)\end{array}$ & $\begin{array}{l}3,5,7,9 \\
12\end{array}$ & (Ciupak et al., 2007) \\
\hline Relative germination coefficient $\mathrm{W}_{\mathrm{k}}$ & $\begin{array}{l}\qquad W_{k}=\frac{1}{n_{\text {control }}} \\
\text { Where: } \\
n(t)-\text { number of seeds germinated in time } \mathrm{t} \text {, } \\
n_{\text {control }}-\text { number of control group seeds germinated in given } \\
\text { time } \mathrm{t}\end{array}$ & $\begin{array}{l}3,5,7,9 \\
12\end{array}$ & (Ciupak et al., 2007) \\
\hline Mean germination time MGT & $\begin{array}{l}\qquad M G T=\frac{\sum D n}{\sum n} \\
\text { where; } \\
\mathrm{n} \text { is the number of germinated seeds on day } \mathrm{D} \\
\mathrm{D} \text { is the number of days counted from the beginning of } \\
\text { germination }\end{array}$ & $\begin{array}{l}3,5,7,9 \\
12\end{array}$ & $\begin{array}{l}\text { (Ellis and Roberts, } \\
\text { 1981) }\end{array}$ \\
\hline Germination index (GI) & $\begin{array}{r}G I=\frac{\text { No. of germinated seeds }}{\text { days of first count }}+- \\
+\frac{\text { No.of germinated seeds }}{\text { days of final count }}\end{array}$ & & (AOSA, 1983) \\
\hline Seedling vigour index (SVI) & $=\sum \frac{\text { SVI }}{\text { Seedling emergence } \% \times \text { Seedling length }(\mathrm{mm})} \frac{100}{100}$ & & $\begin{array}{l}\text { (Abdul-Baki and } \\
\text { Anderson, 1973; } \\
\text { Noghondar \& Azizi, } \\
\text { 2013) }\end{array}$ \\
\hline
\end{tabular}

\section{Statistical analyses}

Analysis of variance test (ANOVA) followed by Duncan's multiple range comparisons were employed to analyse the results of barley after seed irradiation with microwave radiations. Further, correlation and simple linear regression analyses were also performed using 
SPSS statistical software ver. 22 and Microsoft Excel package 2016 at a confidence level of $95 \%$.

\section{RESULTS}

\section{Effect of microwave on germination consequences}

The influence of microwave radiations on various germination dynamics were assessed intensively during the first twelve days after seeds sowings (DAS) in Hordeum vulgare L. plant. Barley seeds were subjected to different exposure doses of microwave radiation from magnetron with $2.45 \mathrm{GHz}$ and 800 Watts. Germination indices monitored and assessed are; number of germinated seeds $\left(\mathrm{n}_{\mathrm{k}}\right)$, percentage of germinated seeds $(\%)$, germination rate $\left(\mathrm{Sk}\right.$; seed. $\left.\mathrm{h}^{-1}\right)$, germination index (GI), and the relative germination coefficient $\left(\mathrm{W}_{\mathrm{k}}\right)$ at different time points 3, 5, 7, 9, and 12 DAS. The percentages of germinated seeds were presented in figs. (2A-E) for different time points $(3,5,7,9$ and 12 DAS; days after sowing). A significant change in the percentage of germinated seeds were observed after seed irradiation with microwave assessed by one-way analysis of variance (ANOVA) followed by Duncan's multiple range comparisons. Significant variations were observed versus the untreated control plant group. The maximum germination percentage observed were $100 \%$ recorded at MW dose of 5 seconds for the $5^{\text {th }}$ DAS as well as 1,5 seconds dose for the $7^{\text {th }}, 9^{\text {th }}$ and $12^{\text {th }}$ DAS. MW radiations observed to have a positive effect on germination at low doses of 1, and 5 seconds (Fig. 2). The general trend of MW radiations on seeds germination percentage was strong negative and significant relationship
(Figures. 4A-E; Table 3) revealed by both regression and Spearman's correlation i.e. increasing levels of MW radiations caused decrease in germination parameters especially high doses of microwave radiations. Other germination indices e.g. germination rate $\left(S_{k}\right.$; seed. $\left.h^{-1}\right)$ were also recorded at different $\mathrm{MW}$ doses and time points $(3,5,7,9,12)$. Germination rate in the untreated control 0.19 seed. $^{-1} 5$ and 7 days after seed sowing while in seeds treated with 1 and 5 seconds of MW the germination rate increased from 0.19 to 0.21 seed.h ${ }^{-1}$ revealing that not only the germination percentage increased but also the germination rate and speed (Figures. 3A-D). Further, early germination was recorded after 1 and 5. Figures (4F-I) represent linear regression trend-line for the effect of $\mathrm{MW}$ radiation on germination rate, which had a strong inverse significant effect (Table 3). Relative germination coefficient $\left(\mathrm{W}_{\mathrm{k}}\right)$ were calculated and normalized to the control germination. Data of relative germination coefficient were presented in figures $(3 \mathrm{E}-\mathrm{H})$ at different time points $(3$, $5,7,9)$; respectively. The relative germination coefficient increased after MW irradiation of 1 and 5 seconds (Figures. 3E-H), while, $\mathrm{W}_{\mathrm{k}}$ decreased after irradiation with higher doses of MW radiations. Linear regression trend-lines presented in figures. (3K-N) represent the linear relationship between $\mathrm{MW}$ radiation doses and relative germination coefficient $\left(\mathrm{W}_{\mathrm{k}}\right)$ after $3,5,7,9$ days after seed sowing. Inverse strong significant relationship between increasing doses of MW radiations and $\mathrm{W}_{\mathrm{k}}$. The germination index (GI) followed the same trend with increasing levels of microwave radiations (Table 3; Figures 2 and 4-O).
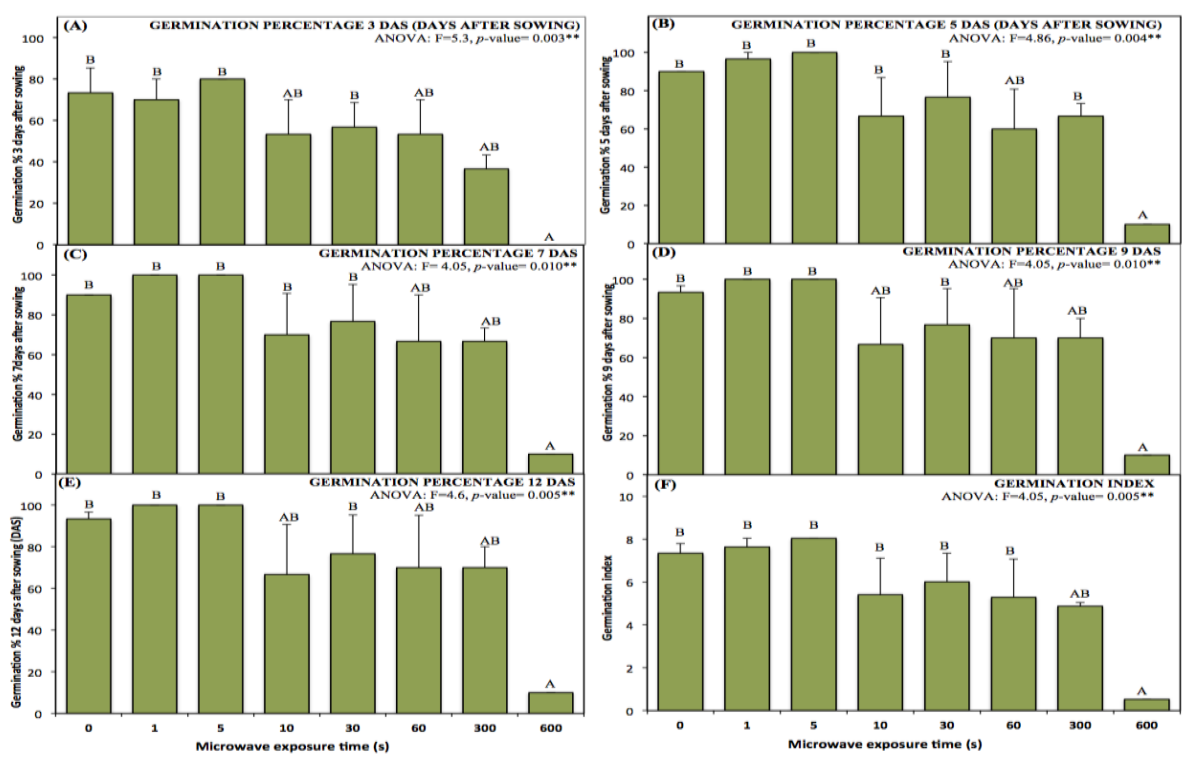

Figure (2): Germination percentage (\%) of barley after pretreatment with microwave radiations recorded after (A) 3, (B) 5, (C) 7, (D) 9, and (E) 12 DAS (days after seed sowing) and $(\mathrm{F})$ germination index. Bars represent mean \pm SEM (standard error for mean) of triplicate treatment. Means with different letters within the same figure are significantly different at $p \leq 0.05, \mathrm{n}=3$ using Duncan's multiple range test. 

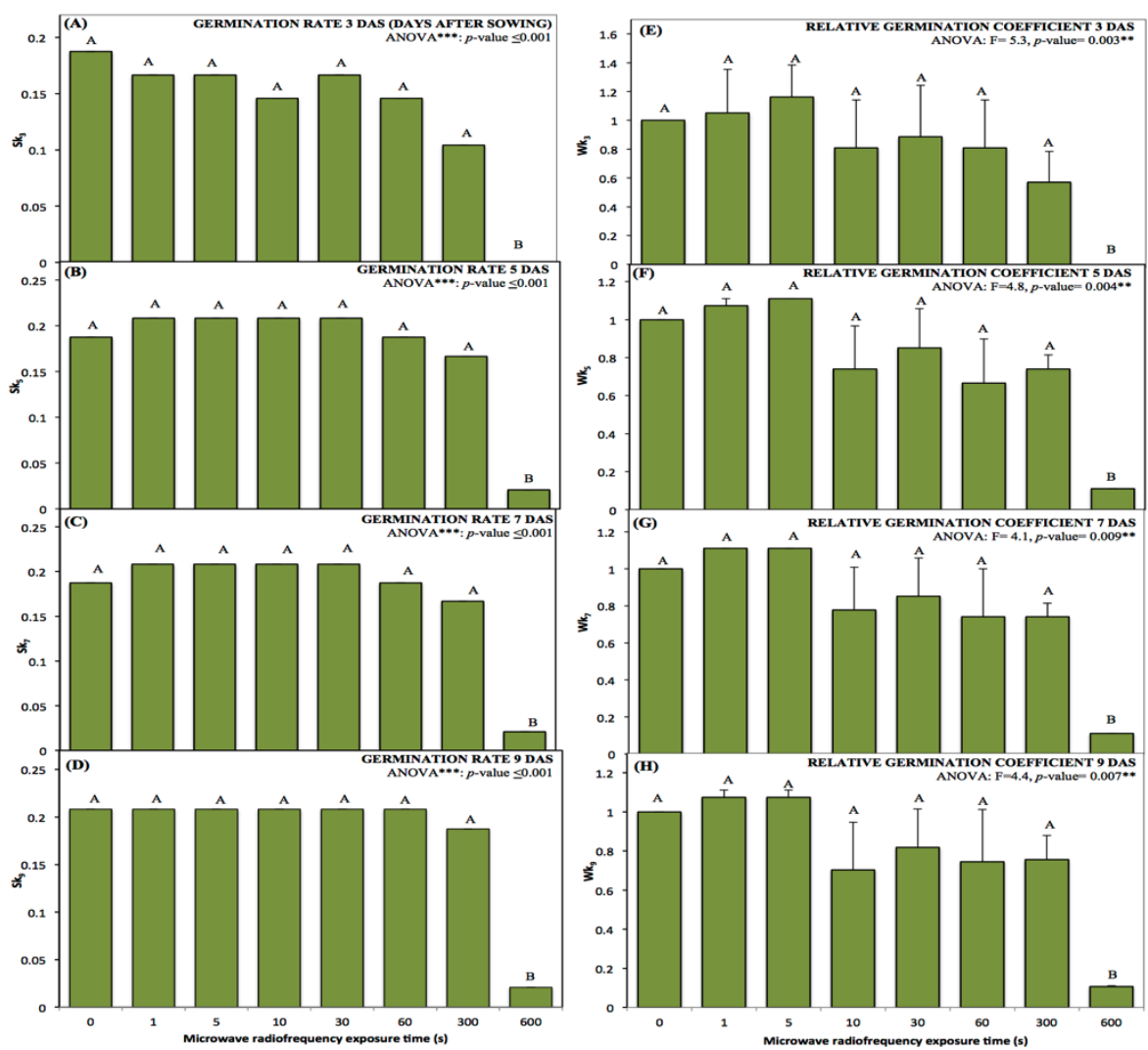

Figure (3): The germination rate $\left(\mathrm{S}_{\mathrm{k}}\right.$ seed. $\left.\mathrm{h}^{-1}\right)$ of $H$. vulgare following pretreatment with microwave radiations recorded after (A) 3 , (B) 5, (C) 7, and (D) 9 DAS. Relative germination index $\left(\mathrm{W}_{\mathrm{k}}\right)$ recorded after (E) 3 (F) 5, (G) 7, (H) 9 DAS. Bars represent mean \pm SEM of triplicate treatment. Means with different letters within the same figure are significantly different at $p \leq 0.05, \mathrm{n}=3 \mathrm{using}$ Duncan's multiple range test.

\section{Microwave effects on growth and photosynthetic pigments}

Shoot and root biomasses were estimated in Hordeum vulgare L. plants after irradiation to MW radiations. Shoot biomass ranged from 0.03 to $0.42 \mathrm{~g} /$ plant-FW where the maximum shoot fresh weight recorded after MW irradiation of 1-second dose and minimum in 600 seconds. Microwave radiations only at the highest duration severely decreased the shoot biomass in barley (Table 2 and Fig. 5A). Root biomass, on the other hand, ranged from 0.03 to $36 \mathrm{~g} / \mathrm{plant}-\mathrm{FW}$. The highest root fresh weight was recorded at $300 \mathrm{~s}$ MW irradiation dose. While minimum root fresh weight were recorded after 600 seconds MW dose (Fig. 5B). Whole plant fresh weight ranged from 0.06 to $0.67 \mathrm{~g} /$ plant-FW. Shoot, root, and whole plant biomass showed a negative trend with increasing levels of MW radiations revealed by simple linear regression analysis and Spearman's correlation (Figures 6A, B and C). Microwave irradiation induced a significant decrease in shoot, root, and plant biomass in barley plants (Figures. 6A, B and C). The behaviour or nutrient allocation was assessed in terms of shoot and root biomass as shoot: root ration (g. $\left.\mathrm{g}^{-1}\right)$ after seed irradiation with MW. Biomass behaveiour was allocated toward barely shoot system after irradiation with 1 second of MW radiations. While, higher doses of MW induced nutrients to be allocated toward root system (Figures 5D and. 4O). Leaf chlorophyll contents increased significantly after 1 and 5 seconds of MW irradiations compared to the control (Table 3 and Fig. 5E), however, MW doses from 300 and 600 seconds decreased significantly from the untreated control. Plant height was monitored after various MW irradiations doses and showed a significant decrease in response to MW (Table 3 and Fig. 5F) revealed by Duncan's multiple range comparisons versus untreated control plants. Root volumes did not change significantly with MW radiations except for the 600 seconds dose which showed a significant decrease versus control (Table 3 and Fig. 6D).

\section{Microwave effects on membrane Ion leakage (\%)}

Microwave radiations with exposure dose of 1 and 60 seconds did not induce change in electrolyte leakage; however, doses of 5, 10, 30, 300 and 600 seconds significantly increased the membrane electrolyte leakage compared to the control (Figures 5H and 6F). A strong inverse highly significant relationship between microwave radiation doses and ion leakage $\left(\mathrm{R}^{2}=0.84\right.$; $\mathrm{r}=$ $0.61 ; p<0.002 *)$. 
Table (2): Growth and germination variables of $H$. vulgare L. seedlings after seed irradiation with various doses of MW radiations at different time points. Data represented as mean of three replicas \pm SEM. Different letters in a row indicate statistically significant differences based on Duncan's multiple range comparisons.

\begin{tabular}{|c|c|c|c|c|c|c|c|c|c|}
\hline \multirow{2}{*}{ Variables } & \multicolumn{8}{|c|}{ MW irradiation doses (seconds) } & \multirow{2}{*}{ F-ratio } \\
\hline & $\mathbf{0}$ & $\mathbf{1}$ & 5 & 10 & 30 & 60 & 300 & 600 & \\
\hline Plant biomass (FW, g) & $0.68 \pm 0.07^{\mathrm{a}}$ & $0.64 \pm 0.02^{\mathrm{a}}$ & $0.65 \pm 0.09^{\mathrm{a}}$ & $0.51 \pm 0.03^{\mathrm{a}}$ & $0.63 \pm 0.11^{\mathrm{a}}$ & $0.57 \pm 0.08^{\mathrm{a}}$ & $0.67 \pm 0.10^{\mathrm{a}}$ & $0.06 \pm 0.0^{\mathrm{b}}$ & $7.5^{* * *}$ \\
\hline Shoot biomass (FW, g) & $0.41 \pm 0.03^{\mathrm{a}}$ & $0.42 \pm 0.04^{\mathrm{a}}$ & $0.32 \pm 0.04^{\mathrm{a}}$ & $0.30 \pm 0.01^{\mathrm{a}}$ & $0.3 \pm 0.06^{\mathrm{a}}$ & $0.30 \pm 0.06^{\mathrm{a}}$ & $0.31 \pm 0.05^{\mathrm{a}}$ & $0.03 \pm 0.0^{\mathrm{b}}$ & $7.6^{* * *}$ \\
\hline Root biomass (FW, g) & $0.27 \pm 0.04^{\mathrm{ab}}$ & $0.22 \pm 0.02^{\mathrm{b}}$ & $0.33 \pm 0.05^{\mathrm{ab}}$ & $0.21 \pm 0.03^{\mathrm{b}}$ & $0.33 \pm 0.05^{\mathrm{ab}}$ & $0.26 \pm 0.02^{\mathrm{ab}}$ & $0.36 \pm 0.05^{\mathrm{b}}$ & $0.03 \pm 0.0^{c}$ & $7.0^{* * *}$ \\
\hline Biomass allocation (g.g ${ }^{-1}$ ) & $1.56 \pm 0.17^{\mathrm{ab}}$ & $1.96 \pm 0.33^{\mathrm{b}}$ & $1.03 \pm 0.14^{\mathrm{ac}}$ & $1.56 \pm 0.33^{\mathrm{ab}}$ & $0.86 \pm 0.06^{\mathrm{c}}$ & $1.13 \pm 0.14^{\mathrm{ac}}$ & $0.86 \pm 0.03^{\mathrm{c}}$ & $1.00 \pm 0.0^{\mathrm{ac}}$ & $4.3^{* *}$ \\
\hline Shoot dry weight (DW, g) & $0.07 \pm 0.01^{\mathrm{a}}$ & $0.04 \pm 0.01^{\mathrm{a}}$ & $0.06 \pm 0.08^{\mathrm{a}}$ & $0.09 \pm 0.05^{\mathrm{a}}$ & $0.03 \pm 0.06^{\mathrm{a}}$ & $0.07 \pm 0.09^{\mathrm{a}}$ & $0.05 \pm 0.10^{\mathrm{a}}$ & $0.03 \pm 0.0^{\mathrm{a}}$ & $0.1 N S$ \\
\hline Root dry weight (DW, g) & $0.16 \pm 0.03^{\mathrm{a}}$ & $0.11 \pm 0.01^{\mathrm{ab}}$ & $0.13 \pm 0.01^{\mathrm{a}}$ & $0.15 \pm 0.06^{\mathrm{a}}$ & $0.12 \pm 0.01^{\mathrm{ab}}$ & $0.12 \pm 0.01^{\mathrm{ab}}$ & $0.17 \pm 0.01^{\mathrm{a}}$ & $0.05 \pm 0.0^{\mathrm{b}}$ & $2.3 N S$ \\
\hline $\mathrm{n}_{\mathrm{K}} 3$ DAS & $7.33 \pm 1.20^{\mathrm{ab}}$ & $7.00 \pm 0.00^{\mathrm{ab}}$ & $8.00 \pm 0.00^{\mathrm{a}}$ & $5.33 \pm 1.66^{\mathrm{ab}}$ & $5.66 \pm 1.20^{\mathrm{ab}}$ & $5.33 \pm 1.66^{\mathrm{ab}}$ & $3.66 \pm 0.66^{b c}$ & $1.00 \pm 0.0^{\mathrm{c}}$ & $4.1 * *$ \\
\hline $\mathbf{n}_{k} 7$ DAS & $9.00 \pm 0.00^{\mathrm{a}}$ & $10.0 \pm 0.00^{\mathrm{a}}$ & $10.00 \pm 0.0^{\mathrm{a}}$ & $7.00 \pm 2.08^{\mathrm{a}}$ & $7.66 \pm 1.85^{\mathrm{a}}$ & $6.66 \pm 2.33^{\mathrm{a}}$ & $6.66 \pm 0.66^{\mathrm{a}}$ & $1.00 \pm 0.0^{\mathrm{b}}$ & $4.9 * *$ \\
\hline $\mathbf{n}_{k} 9$ DAS & $9.33 \pm 0.33^{\mathrm{a}}$ & $10.0 \pm 0.00^{\mathrm{a}}$ & $10.00 \pm 0.0^{\mathrm{a}}$ & $6.66 \pm 2.40^{\mathrm{a}}$ & $7.66 \pm 1.85^{\mathrm{a}}$ & $7.00 \pm 2.52^{\mathrm{a}}$ & $7.00 \pm 1.00^{\mathrm{a}}$ & $1.00 \pm 0.0^{\mathrm{b}}$ & $4.1 * *$ \\
\hline$n_{k} 12$ DAS & $9.33 \pm 0.33^{\mathrm{a}}$ & $10.0 \pm 0.00^{\mathrm{a}}$ & $10.00 \pm 0.0^{\mathrm{a}}$ & $6.66 \pm 2.40^{\mathrm{a}}$ & $7.66 \pm 1.85^{\mathrm{a}}$ & $7.00 \pm 2.52^{\mathrm{a}}$ & $7.00 \pm 1.00^{\mathrm{a}}$ & $1.00 \pm 0.0^{\mathrm{b}}$ & $4.1 * *$ \\
\hline VI 3 DAS & $145.9 \pm 23^{\mathrm{ab}}$ & $139.3 \pm 19^{\mathrm{ab}}$ & $159.2 \pm 0.0^{\mathrm{b}}$ & $106.1 \pm 33^{\mathrm{ab}}$ & $112.7 \pm 23^{\mathrm{ab}}$ & $106.1 \pm 33^{\mathrm{ab}}$ & $72.9 \pm 13.3^{b}$ & $1.99 \pm 0.0^{\mathrm{c}}$ & $5.1 * *$ \\
\hline VI 5 DAS & $179.1 \pm 0.0^{\mathrm{a}}$ & $192.4 \pm 6.0^{\mathrm{a}}$ & $199.0 \pm 0.0^{\mathrm{a}}$ & $132.6 \pm 40^{\mathrm{a}}$ & $152.5 \pm 36^{\mathrm{a}}$ & $119.4 \pm 41^{\mathrm{a}}$ & $132.6 \pm 13^{\mathrm{a}}$ & $19.9 \pm 0.0^{\mathrm{b}}$ & $5.3^{* *}$ \\
\hline GI 3 DAS & $2.44 \pm 0.40^{\mathrm{ab}}$ & $2.33 \pm 0.33^{\mathrm{ab}}$ & $2.66 \pm 0.00^{b}$ & $1.77 \pm 0.55^{\mathrm{ab}}$ & $1.88 \pm 0.40^{\mathrm{ab}}$ & $1.77 \pm 0.55^{\mathrm{ab}}$ & $1.22 \pm 0.22^{\mathrm{b}}$ & $0.00 \pm 0.0^{\mathrm{c}}$ & $5.2 * *$ \\
\hline GI 5 DAS & $1.80 \pm 0.00^{\mathrm{a}}$ & $1.93 \pm 0.06^{\mathrm{a}}$ & $2.00 \pm 0.00^{\mathrm{a}}$ & $1.33 \pm 0.40^{\mathrm{a}}$ & $1.53 \pm 0.37^{\mathrm{a}}$ & $1.2 \pm 0.416^{\mathrm{a}}$ & $1.33 \pm 0.13^{\mathrm{a}}$ & $0.20 \pm 0.0^{\mathrm{b}}$ & $5.3^{* *}$ \\
\hline GI 7 DAS & $1.28 \pm 0.00^{\mathrm{a}}$ & $1.42 \pm 0.00^{\mathrm{a}}$ & $1.42 \pm 0.00^{\mathrm{a}}$ & $1.00 \pm 0.29^{\mathrm{a}}$ & $1.09 \pm 0.26^{\mathrm{a}}$ & $0.95 \pm 0.33^{\mathrm{a}}$ & $0.95 \pm 0.09^{\mathrm{a}}$ & $0.14 \pm 0.0^{\mathrm{b}}$ & $4.9 * *$ \\
\hline GI 9 DAS & $1.03 \pm 0.04^{\mathrm{a}}$ & $1.11 \pm 0.00^{\mathrm{a}}$ & $1.11 \pm 0.00^{\mathrm{a}}$ & $0.74 \pm 0.26^{\mathrm{a}}$ & $0.85 \pm 0.20^{\mathrm{a}}$ & $0.77 \pm 0.28^{\mathrm{a}}$ & $0.77 \pm 0.11^{\mathrm{a}}$ & $0.11 \pm 0.0^{\mathrm{b}}$ & $4.1 * *$ \\
\hline GI & $7.34 \pm 0.45^{\mathrm{a}}$ & $7.63 \pm 0.40^{\mathrm{a}}$ & $8.03 \pm 0.00^{\mathrm{a}}$ & $5.40 \pm 1.70^{\mathrm{a}}$ & $6.00 \pm 1.33^{\mathrm{a}}$ & $5.29 \pm 1.77^{\mathrm{a}}$ & $4.86 \pm 0.17^{\mathrm{a}}$ & $0.53 \pm 0.0^{\mathrm{b}}$ & $5.5^{* *}$ \\
\hline MGT 3 DAS & $2.44 \pm 0.40^{\mathrm{ab}}$ & $2.33 \pm 0.33^{\mathrm{ab}}$ & $2.66 \pm 0.00^{b}$ & $1.77 \pm 0.55^{\mathrm{ab}}$ & $1.88 \pm 0.40^{\mathrm{ab}}$ & $1.77 \pm 0.55^{\mathrm{ab}}$ & $1.22 \pm 0.22^{b}$ & $0.00 \pm 0.0^{\mathrm{c}}$ & $5.2 * *$ \\
\hline MGT 5 DAS & $1.80 \pm 0.00^{\mathrm{a}}$ & $1.93 \pm 0.06^{\mathrm{a}}$ & $2.00 \pm 0.00^{\mathrm{a}}$ & $1.33 \pm 0.40^{\mathrm{a}}$ & $1.53 \pm 0.37^{\mathrm{a}}$ & $1.20 \pm 0.42^{\mathrm{a}}$ & $1.33 \pm 0.13^{\mathrm{a}}$ & $0.20 \pm 0.0^{\mathrm{b}}$ & $5.3^{* *}$ \\
\hline MGT 7 DAS & $1.28 \pm 0.00^{\mathrm{a}}$ & $1.42 \pm 0.00^{\mathrm{a}}$ & $1.42 \pm 0.00^{\mathrm{a}}$ & $1.00 \pm 0.29^{\mathrm{a}}$ & $1.09 \pm 0.26^{\mathrm{a}}$ & $0.95 \pm 0.33^{\mathrm{a}}$ & $0.95 \pm 0.09^{\mathrm{a}}$ & $0.14 \pm 0.0^{\mathrm{b}}$ & $4.9 * *$ \\
\hline MGT 9 DAS & $1.03 \pm 0.04^{\mathrm{a}}$ & $1.11 \pm 0.00^{\mathrm{a}}$ & $1.11 \pm 0.00^{\mathrm{a}}$ & $0.74 \pm 0.26^{\mathrm{a}}$ & $0.85 \pm 0.20^{\mathrm{a}}$ & $0.77 \pm 0.28^{\mathrm{a}}$ & $0.77 \pm 0.11^{\mathrm{a}}$ & $0.11 \pm 0.0^{\mathrm{b}}$ & $4.1 * *$ \\
\hline MGT 12 DAS & $0.77 \pm 0.03^{\mathrm{a}}$ & $0.83 \pm 0.00^{\mathrm{a}}$ & $0.83 \pm 0.00^{\mathrm{a}}$ & $0.55 \pm 0.20^{\mathrm{a}}$ & $0.63 \pm 0.15^{\mathrm{a}}$ & $0.58 \pm 0.21^{\mathrm{a}}$ & $0.58 \pm 0.08^{\mathrm{a}}$ & $0.08 \pm 0.0^{\mathrm{b}}$ & $4.1 * *$ \\
\hline
\end{tabular}

\section{DISCUSSION}

Microwave irradiation with different exposure doses induced changes in various parameters of barley (H. vulgare genotype Giza-129). Germination parameters were dose-dependent and were stimulated by several exposure doses of microwave radiations. The percentage of germinated grains (Figures 2A-E), germination rate (Figures 3A-D), relative germination coefficient (Figures 3E-H) and germination index (Fig. 2F) at different time points were increased by short exp- osure to microwave radiations, however, high exposure doses of microwave induced a significant decrease in germination consequences. Further, various growth parameters of barley (H. vulgare genotype Giza-129) were increased by one or more low doses of microwave radiations and were significantly decreased by higher exposure doses. These results were found to be in agreement with Ragha et al. (2011), Crețescu et al. (2013), and Abu-Elsaoud (2015). The low power microwave irradiation reduces the rate and percentage of germination in radish seeds and increases germination mean time, thus impairing seed germination. 

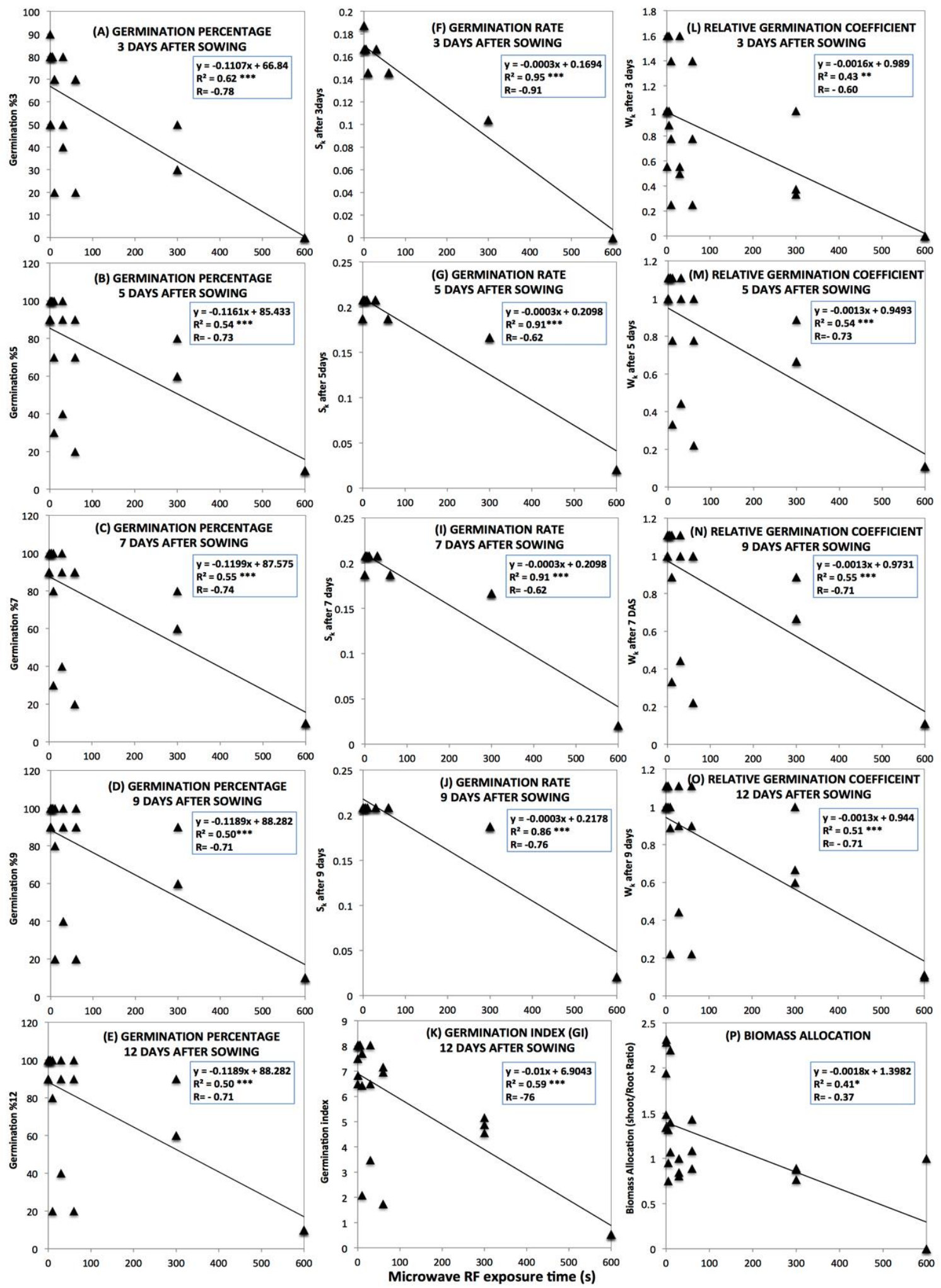

Figure (4 A-O): Regression trendline showing the relationship between microwave exposure doses and various germination indices of $H$. vulgare L., correlations were tested statistically using Simple linear regression, Spearman's correlation and 2-tailed significance test at $p \leq 0.05$. 


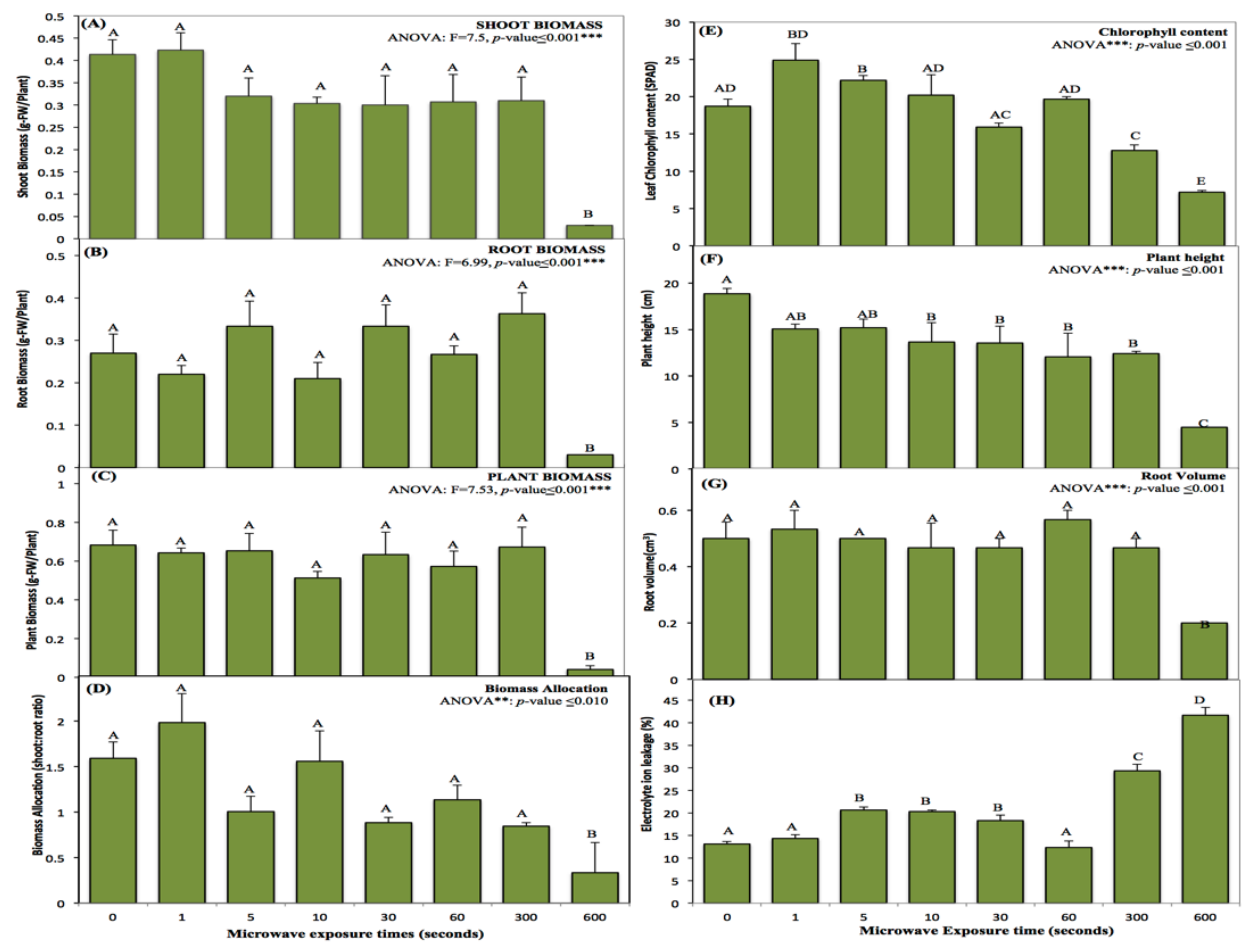

Figure (5 A-H): Shoot biomass, (B) root biomass, (C) plant biomass (g-FW/plant), (D) biomass allocation (shoot:root ratio; g. $\mathrm{g}^{-1}$ ), (E) Chlorophyll content, (F) Plant height (cm), (G) Root volume $\left(\mathrm{cm}^{3}\right)$, and (H) Membrane electrolyte leakage (\%) of $H$. vulgare irradiated with microwave. Bars represent mean \pm SEM of triplicate treatment. Means with different letters within the same figures are significantly different at $p \leq 0.05, \mathrm{n}=3$ using Duncan's multiple range test.

Table (3): Spearman's correlation coefficient (R) and two-tailed significance at $p<0.05$ for barley seedling measured variables after pretreatment with MW radiations.

\begin{tabular}{|c|c|c|}
\hline Variables correlation to microwave irradiation doses & Correlation coefficient & Sig.2-tailed \\
\hline Chlorophyll contents & -0.38 & 0.070 n.s. \\
\hline Plant height (cm) & -0.79 & $0.000 * * *$ \\
\hline Plant Root volume $\left(\mathrm{cm}^{3}\right)$ & -0.39 & 0.057 n.s. \\
\hline Plant biomass (g-FW/plant) & -0.72 & $0.000 * * *$ \\
\hline Shoot biomass (g-FW/plant) & -0.68 & $0.000 * * *$ \\
\hline Root biomass (g-FW/plant) & -0.69 & $0.001 * * *$ \\
\hline Biomass allocation (g.g-1) & -0.69 & $0.000 * * *$ \\
\hline Shoot dry weight (g.DW/plant) & -0.23 & 0.276 n.s. \\
\hline Root dry weight (g.DW/plant) & -0.26 & 0.224 n.s. \\
\hline Ion Leakage (\%) & -0.57 & $0.003 * *$ \\
\hline nK 3 DAS & -0.74 & $0.000 * * *$ \\
\hline nk 5 DAS & -0.69 & $0.000 * * *$ \\
\hline nk 7 DAS & -0.69 & $0.000 * * *$ \\
\hline nk 9 DAS & -0.66 & $0.000 * * *$ \\
\hline nk 12 DAS & -0.66 & $0.000 * * *$ \\
\hline VI 3 DAS & -0.73 & $0.000 * * *$ \\
\hline VI 5 DAS & -0.69 & $0.000 * * *$ \\
\hline GI 3 DAS & -0.73 & $0.000 * * *$ \\
\hline GI 5 DAS & -0.68 & $0.000 * * *$ \\
\hline GI 7 DAS & -0.69 & $0.000 * * *$ \\
\hline GI 9 DAS & -0.66 & $0.000 * * *$ \\
\hline GI 12 DAS & -0.66 & $0.000 * * *$ \\
\hline Germination index (GI) & -0.69 & $0.000 * * *$ \\
\hline MGT 3 days after sowing & -0.73 & $0.000 * * *$ \\
\hline MGT 5 days after sowing & -0.69 & $0.000 * * *$ \\
\hline MGT 7 days after sowing & -0.69 & $0.000 * * *$ \\
\hline MGT 9 days after sowing & -0.66 & $0.000 * * *$ \\
\hline MGT 12 days after sowing & -0.66 & $0.000 * * *$ \\
\hline
\end{tabular}





Figure (6 A-G): Regression trend-line showing the relationship between microwave exposure doses versus shoot and root growth, chlorophyll contents, and membrane ion leakage (\%). Correlations were tested statistically using simple linear regression, Spearman's correlation and 2-tailed significance test at $p \leq 0.05$.

The germination reduction is linearly dependent on the MW power intensity incident on the seed. These findings support the simplified hypothesis that the power density on a plane perpendicular to wave direction decreases with the inverse square of distance from the source (Scialabba and Tamburello, 2002). The effect of Microwave radiofrequency irradiation is thought to be a dose-dependent effect that is significantly differing from irradiation dose to another. There is contradictory information about the effect of microwave radiofrequency on germination of seeds; decreased germination was reported previously by Monteiro et al. (2008). Moreover, the effect of microwave on various growth e.g. germination rate and shoot growth rate showed that microwave radiofrequencies possibly retard germination but the consequence on tubule growth is uncertain and 
the data from ongoing experimentations conveyed statistically expressive results (Monteiro et al., 2008). The decrease in seed viability and germination with microwave were in accordance with results of Brodie $e t$ al. (2012) that microwave treatment of paddy melon reduced seed viability by $60-70 \%$. This is also consistent with other studies (Aladjadjiyan, 2002; Scialabba and Tamburello, 2002; Chen et al., 2005; VelázquezMartí et al., 2006; Tkalec et al., 2007; Khalafallah et al., 2009; Fuangfoong et al., 2013; Abu-Elsaoud, 2015). Additional advantages of microwave treatment such as increase in seed germination have been recorded by current study and were consistent with patterns reported by (Aladjadjian and Svetleva, 1997; Reddy et al., 1998; Aladjadjiyan, 2007).

The effect of microwave on germination could be due to thermal effect of microwave and hence, low moisture content (Manickavasagan et al., 2007) and is also related to initial moisture contents of grains (Campana et al., 1993). These can be explained in terms of absorbed energy, higher output power of the radiation, as well as longer exposure time, lead to absorption of more energy by the object. Higher energies cause heating. The accelerated germination and improved germinating energy of certain doses in current study $(1,5 \mathrm{~s})$ could be due to the eventual disturbance of the seed coat under the influence of the microwave treatment, which facilitated water penetration into the seeds and the start of the initial development stages (Iuliana et al., 2013). Aladjadiyan (2007) suggests that the energy introduced into the plant cells microwaves creates conditions for molecular transformations which may have resulted in providing necessary substances for the cell, thus improving seed quality parameters. However, a tendency for an increase in the percentage of morphologically abnormal seedlings was observed with the prolonged treatment. This may indicate a risk of inducing some deleterious effects in the seed subjected to microwaves which was shown by Reddy et al. (2000) for soybean seeds treated with microwaves longer than $30 \mathrm{~s}$ and in accordance with decreased barley germination with high doses of microwave in current studies.

Various growth parameters of barley (H. vulgare genotype Giza-129) e.g. shoot and root biomasses, biomass allocation, chlorophyll contents showed a slight increase at low microwave exposure doses and decreesed growth at high doses (600s). The increase of growth rate upon irradiation removal shows that during the elongation growth, the cell can partially repair damages occurred at the membrane level. There is a general consensus of opinion about the fact that MW induces a thermal detrimental effect over biological system (Scialabba and Tamburello, 2002). In the present case we assume that the damage induced by the low-power microwave exposure is non-thermal because a slight temperature increase (up to $25^{\circ} \mathrm{C}$ ) over radish seeds has been demonstrated to induce germination and growth increase (Scialabba and Tamburello, 2002). The reduced germination percentage and the delayed seedling growth confirm the importance of a serious cause of concern about the influence of exposure to environmental MW fields. It can be stressed the importance of limiting in time the exposure to MW as suggested by the recovering ability of the biological system considered in the present research.

Chlorophyll contents increased in barley after irradiations with low doses of microwave $(1,5,10$, and $60 \mathrm{~s})$ and decreased in other exposure doses $(30,300$, and 600 s). A possible explanation by Aladjadjiyan (2002) that suggests a hypothesis about the absorption of the microwave radiation energy by the hydrogen or magnesium atom's electrons in the chlorophyll molecule. The energy absorbed is redistributed and it causes changes in the chlorophyll molecule.

The exposure to specific microwave radiofrequency wavelength enhanced growth of Spirulina platensis by about 50\% (Pakhomov et al., 1998). Microwaves radiofrequency can reduces the trans-membranous protein channel-opening possibly because microwaves induce the modification of intracellular enzymatic processes e.g. protein kinase activation (D'Inzeo et al., 1988). Aquaporin are a plant cell water channel proteins of cellular and vacuole membranes that are involved in water movement's dynamic regulation throughout plant growth, development and stress responses (Maurel, 1997). Possible microwave effect in a research carried out on case of radish seedlings, through reducing the water passage across cell membrane, closing the aquaporins and resulting in reduction of growth in a turgordependent manner (Scialabba and Tamburello, 2002). Vibration of water molecule dipoles induced by microwave radiation gives thermal effect, which according to van't Hoff's rule and Arrhenius law affects reaction rate in biological processes. Increase in the rate of biochemical changes in may result in accelerated or intensified production of auxins and glutathione, which are growth activators (Jakubowski, 2008). Additional factors affecting germs biomass growth may include circulation and supplying buds with spare substances necessary to commence germination process, also connected with the rate of biochemical changes (Jakubowski, 2008). If seed potato germination process accelerates due to microwave radiation (Jakubowski, 2008 and 2010), this effect will have influence on successive plant ontogenesis stages, including vegetation period reduction or cropping size. It is also possible that microwave radiation energy received by seeds during stimulation will be converted into other energy forms similar to those acquired by tuber through organic substances combustion (Jakubowski, 2010). This mechanism would directly translate into processes involved in the conversion and carrying spare substances from mother tuber into other parts of the plant. This phenolmenon may also affect intensity of some photosynthesis stages, supply of assimilates, the size and nature of energy conversions, and broadly understood action of enzymatic systems in a plant (Jakubowski, 2010). In previous research involved the impact of 
physical methods on potato plants such effect was explained by thermal and athermal action of microwave radiation on seed potatoes (Jakubowski, 2015). The microwaves penetrating the seed potato cause oscillation of ions in the electrolytes and of molecules in polarized dielectrics (Banik et al., 2003), as a result of which the waterlogged tuber can become heated. A thermal effect takes place when as a result of absorption of electromagnetic radiation energy the object temperature increases by more than $0.2^{\circ} \mathrm{C}$ (Jakubowski, 2015). The thermal effects depend also on the ratio of the size of the irradiated object to the wavelength and the object placement in relation to the direction of magnetic eld vector. Jethon and Gryzybowski (2000) claim that microwaves can cause changes in the organisms' adaptation systems and the effects on these systems can include bioelectric, metabolic and structural changes.

Variations in plant growth with fixed power intensities and varied exposure times in current study could be explained that there is certain specific micro-wave power density that is suitable for plant growth (Fuangfoong et al., 2013).

Membrane electrolyte leakage accompanies the plant response to stresses were monitored at different microwave exposure doses. Microwave radiations induced a significant increase in membrane ion leakage in barley (Hordeum vulgare L.) leaves except for doses 1 and 60 seconds, which were not changed significantly from control (Figures $5 \mathrm{H}$ and $6 \mathrm{~F}$ ). Electrolyte leakage is widely used as a measure of stress induced injury in plants (Lee and Zhu, 2010). According to our results microwave radiation with dose 1 and 60 seconds did not induce change in electrolyte leakage. The rising trend of electrolyte leakage may be ascribed to the acceleration of material exchange inside and outside the cells induced by the microwave irradiation due to the loss of enzyme activity within the cell membrane. Hence, the metal ions were excluded through the membrane, leading to a significant increase of electrolyte leakage (Woo et al., 2000). Cojocaru et al. (2005) proposed another explanation for the increase in electrical conductivity induced by high-intensity microwave irradiation: the activation of lipid peroxidation by metal ions led to the damage of the phospholipid membrane. Additionally, the cell membrane blockage caused by the aggregation and denaturation of the intracellular biomacromolecules resulted in a slight decrease of electrolyte leakage 1 and 60s, which has been confirmed by another study the microwave effect on Aspergillus (Fang et al., 2011).

In current research microwave doses from 5 to 600 seconds significantly increased membrane electrolyte leakage compared to the control. These results are in agreement with previous results of Aladjadjiyan (2002) and Demidchik et al. (2014). By increasing the radiation power used for the treatment of the samples, the amount of free ions in the extract decreases and hence its electroconductivity (Aladjadjiyan, 2002). Microwave exposure reduces trans-membrane protein channels ope- ning in cultured chick myotubes probably through alteration of intracellular enzymatic processes e.g. protein kinase activation (D'Inzeo et al., 1988). In plant cells, protein of water channels namely aquaporins of vacuolar membranes and plasma membranes are involved in the regulation of water movement dynamics in growth and development of plant cell and in stress responses (Maurel, 1997). In case of radish seedlings, microwaves may reduce water passage across cell membrane blocking aquaporins and causing reduction of growth in a turgor-dependent manner (Scialabba and Tamburello, 2002).

Membrane Electrolyte leakage is an essential measure of the plants' responses to various stresses. It is mostly associated with the $\mathrm{K}^{+}$efflux, which is a common response in plant cells (Demidchik et al., 2014). The stress-induced electrolyte leakage is always accompanied by reactive oxygen species (ROS) generation and hence, leads to programmed cell death. Recent results exhibited that reactive oxygen species (ROS; $\mathrm{H}_{2} \mathrm{O}_{2}$ and hydroxyl radicals) activates annexins, SKOR and GORK genes that catalyses $\mathrm{K}^{+}$efflux from plant cells (Demidchik et al., 2014). Further, GORK-genes mediated potassium ion $\left(\mathrm{K}^{+}\right)$cause programmed cell death under oxidative stress. The intracellular endonucleases and proteases seem to be blocked by potassium ions; consequently, the efflux of these $\mathrm{K}^{+}$to the extracellular stimulates the intracellular nucleases and proteases hydrolytic enzymes causing programmed cell death (PCD). Potassium ions could play a "metabolic switch" role under moderate stress conditions decreasing the anabolic reactions rate and stimulating catabolic reactions, leading to the release ofenergy required for repairing and adaptation needs (Demidchik et al., 2014).

In current study microwave doses of 5 and 60 showed increased and decreased ion leakage which may be related to certain exposure doses to have positive and other negative effects that is consistent with Grundler et al. (1982) that the yeast growth rate could be increased or decreased pattern after irradiation with certain microwave frequencies.

The effect of microwaves on plants was the main purpose of the current study. Since it is a known problem, many other researches were done on this topic. Having seen and observed other projects, we noticed that the major conflict was between whether microwaves affect plants germination or not. Our hypothesis was that they do affect it and, of course, it is well known that they do but it still made a challenge trying to prove it and it was found that every single step affected the results. Since it is likely that other people who did similar projects have done some errors through their study, the results were not reliable and could not be considered accurate enough.

\section{CONCLUSION}

Microwave had both positive and negative effects on plants growth and germination. However it induced 
membrane ion leakage especially at high microwave exposure doses. Various germination and growth parameters showed a dose-dependent effect, where, low doses stimulated germination and growth, however, higher microwave doses inhibited germination and decreased growth. Current research data offered a spotlight on both positive and negative effects of microwave radiations on barley. The effect of Microwave radiation could have positive effect by controlling doses and minimizing the exposure time of seeds to microwave radiations.

\section{REFERENCES}

ABDUL-BAKI, A.A. AND J.D. ANDERSON. 1973. Vigor Determination in Soybean Seed by Multiple Criteria. Crop Science 13 (6): 630-633.

ABU-ELSAOUD, A.M. 2015. Effect microwave electromagnetic radiofrequency on germination and seedling growth consequences of six wheat Triticum aestivum cultivar. Advances in Environmental Bio$\operatorname{logy} 9$ (24): 270-281.

ALADJADJIAN, A., AND D. SVETLEVA 1997. Influence of magnetron irradiation on common bean (Phaseolus vulgaris L.) seeds. Bulgarian Journal of Agricultural Science. Available from: https:// eurekamag.com/research/003/175/003175295.php (March 26, 2017).

ALADJADJIYAN, A. 2002. Influence of microwave irradiation on some vitality indices and electroconductivity of ornamental perennial crops. Journal of Central European Agriculture 3 (4).

ALADJADJIYAN, A. 2007. The use of physical methods for plant growing stimulation in Bulgaria. Journal of Central European Agriculture 8 (3): 369 380.

ALADJADJIYAN, A. 2010. Effect of microwave irradiation on seeds of lentils (Lens culinaris, med.). Romanian Journal of Biophysics 20 (3): 213-221.

AOSA, I. 1983. Seed vigor testing handbook. Association of Official Seed Analysts. Contribution 32.

BALMORI, A. 2009. Electromagnetic pollution from phone masts. Effects on wildlife. Pathophysiology: the official journal of the International Society for Pathophysiology / ISP 16 (2-3): 191-199.

BANIK, S., S. BANDYOPADHYAY, AND S. GANGULY. 2003. Bioeffects of microwave a brief review. Bioresource technology 87 (2): 155-159.

BELYAEV, I. 2005. Non-thermal biological effects of microwaves. Microwave Review 11 (2): 13-29.

BOCZOŃ, A., M. WRÓBEL, AND W. PTACH. 2009. Effects of hydrogel application on growth of seedlings on unproductive forest areas. Ekologija $\mathbf{5 5}$ (1): 9-19.

BRODIE, G., C. RYAN, AND C. LANCASTER. 2012. The Effect of Microwave Radiation on Prickly Paddy Melon (Cucumis myriocarpus). International Journal of Agronomy 1-10.
CAMPANA, L.E., M.E. SEMPE, AND R.R. FILGUEIRA. 1993. Physical, chemical, and baking properties of wheat dried with microwave energy. Cereal chemistry.

CAMPOS, P.S., V.N. QUARTIN, J. CHICHO RAMALHO, AND M.A. NUNES. 2003. Electrolyte leakage and lipid degradation account for cold sensitivity in leaves of Coffee sp. plants. Journal of plant physiology 160 (3): 283-292.

CHEN, Y.P., Y.J. LIU, X. L. WANG, Z. Y. REN, AND M. YUE. 2005. Effect of Microwave and He-Ne Laser on Enzyme Activity and Biophoton Emission of Isatis indigotica Fort. Journal of Integrative Plant Biology 47 (7): 849-855.

CIUPAK, A., I. SZCZUROWSKA, B. GŁADYSZEWSKA, AND S. PIETRUSZEWSKI. 2007. Germination of Buckwhet Seeds Subject to Storage Time and Electromagnetic Stimulation Methods. Technical Sciences 10 (1): 11-18.

COJOCARU, A.F., N L. COJOCARU, AND Z.I. BURKOVETSAKAYA. 2005. Mechanisms of water-mediated action of weak radio-frequency electro-magnetic radiation on biological objects. Biophysics 50: S141-S156.

CREȚESCU, I., R. CĂPRIŢĂ, G. VELICEVICI, S. ROPCIUC, AND G. BUZAMAT. 2013. Response of Barley Seedlings to Microwaves at $2.45 \mathrm{GHz}$. Scientific Papers Animal Science and Biotechnologies 46 (1): 185-191.

D'INZEO, G., P. BERNARDI, F. GRASSI, B.M. ZANI, F. EUSEBI, AND C. TAMBURELLO. 1988. Microwave effects on acetylcholine-induced channels in cultured chick myotubes. Bioelectromagnetics 9 (4): 363-372.

DEMIDCHIK, V., D. STRALTSOVA, S.S. MEDVEDEV, G. A. POZHVANOV, A. SOKOLIK, AND V. YURIN. 2014. Stress-induced electrolyte leakage: the role of $\mathrm{K}+$ permeable channels and involvement in programmed cell death and metabolic adjustment. Journal of Experimental Botany $\mathbf{6 5}$ (5): 1259-1270.

ELLIS, R.H. AND E.H. ROBERTS. 1981. The quantification of ageing and survival in orthodox seeds. Seed Science and Technolog 9: 373-409.

EMC 2007. IEEE International Symposium on. 1-4. IEEE.

FANG, Y., J. HU, S. XIONG, AND S. ZHAO. 2011. Effect of low-dose microwave radiation on Aspergillus parasiticus. Food Control 22 (7): 10781084.

FUANGFOONG, M., K. EAIPRESERTSAK, T. CHIM-OYE, AND K. DUNGKANYA. 2013. Effect of low-power microwave radiation on seed growth rate. Session 2P8: 409.

GRUNDLER, W., F. KEILMANN, V. PUTTERLIK, AND D. STRUBE. 1982. Resonant-like dependence of yeast growth rate on microwave frequencies. The British Journal of Cancer. Supplement 5: 206-208. 
HUTTER, H.P., H. MOSHAMMER, P. WALLNER, AND M. KUNDI. 2006. Subjective symptoms, sleeping problems, and cognitive performance in subjects living near mobile phone base stations. Occupational and Environmental Medicine 63 (5): 307-313.

IULIANA, C., V. GIANCARLA, AND R. SORINA. 2013. The effect of microwave irradiation on the germination of barley seeds (Hordeum vulgare L.). In: 254-258. Poljoprivredni Fakultet Sveučilište Josipa Jurja Strossmayera u Osijeku.

JAKUBOWSKI, T. 2008. The impact of microwave radiation on potato tuber germs growth dynamics. Periodical Inżynieria Rolnicza 5 (103): 7-13.

JAKUBOWSKI, T. 2010. The impact of microwave radiation at different frequencies on weight of seed potato germs and crop of potato tubers. Inżynieria Rolnicza 14: 57-64.

JAKUBOWSKI, T. 2015. Transfer of microwave irradiation effects of seed potatoes (Solanum tuberosum L.) to the plants of next generations. Bulgarian Journal of Agricultural Science 21 (6): 1185-1193.

JETHON, Z. AND A. GRYZYBOWSKI, 2000. Preventive Medicine and Environmental. PZWL Medical Publishing 13-18 (in Polish). In JAKUBOWSKI, T. 2015. Transfer of microwave irradiation effects of seed potatoes (Solanum tuberosum L.) to the plants of next generat-ions. Bulgarian Journal of Agricultural Science 21, 11851193.

KEMEROV, S., M. MARINKEV, AND D. GETOVA 1999. Effects of low-intensity electromagnetic fields on behavioral activity of rats. Folia Medica 41 (3): 75-80.

KHALAFALLAH, AND A.S. SALLAM. 2009. Response of maize seedlings to microwaves at 945 MHz. Romanian J. Biophys 19 (1): 49-62.

KOSITSKY, N.N., A.I. NIZHELSKA, AND G.V. PONEZHA. 2001. Influence of high-frequency electromagnetic radiation at non-thermal intensities on the human body. No Place To Hide-Newsletter of the Cellular Phone Taskforce Inc 3 (1): 1-33.

LAI, H. 2005. Biological effects of radiofrequency electromagnetic field. Encyclopedia of Biomaterials and Biomedical Engineering 10: 1-8.

LEE, B.H., AND J.K. ZHU. 2010. Phenotypic analysis of Arabidopsis mutants: electrolyte leakage after freezing stress. Cold Spring Harbor Protocols 2010 (1): pdb.prot4970.

LIN, J.C. 2004. Evaluating scientific literature on biological effects of microwave radiation. IEEE Microwave Magazine 5 (1): 34-37.

MANICKAVASAGAN, A., D.S. JAYAS, AND N.D.G. WHITE. 2007. Germination of wheat grains from uneven microwave heating in an industrial microwave dryer. Canadian Biosystems Engineering 49: 3 .
MAUREL, C. 1997. Aquaporins and water permeability of plant membranes. Annual Review of Plant Physiology and Plant Molecular Biology 48: 399 429.

MAZEN, A.M., D.E.M. RADWAN, AND A.F. AHMED. 2015. Growth Responses of Maize Plants Cultivated in Sandy Soil Amended by Different Superabsorbant Hydrogels. Journal of Plant Nutrition 38 (3): 325-337.

MONTEIRO, J.H., S.K. MENDIRATTA, AND A. CAPITAO. 2008. Effect of microwave fields on the germination period and shoot growth rate of some seeds. In: International Conference on Recent Advances in Microwave Theory and Applications, 2008. MICROWAVE 792-793.

NOGHONDAR, M.A., AND M. AZIZI. 2013. Seed Harvesting Time Affects Seedling Emergence, Vigour and Growth: Case Study of Rumex turcomanicus Czerep. (Polygonaceae). Notulae Scientia Biologicae 5 (2): 244-248.

NOVICHONOK, E.V., A.O. NOVICHONOK, J.A. KURBATOVA, AND E.F. MARKOVSKAYA 2016. Use of the atLEAF+ chlorophyll meter for a nondestructive estimate of chlorophyll content. Photosynthetica 54 (1): 130-137.

OPRICA, L. 2008. Effect of microwave on the dynamics of some oxidoreductase enzymes in Brassica napus germination seeds. Analele Stiintifice ale Universitatii "Alexandru Ioan Cuza" din Iasi Sec. II a. Genetica si Biologie Moleculara 9 (3).

PAKHOMOV, A.G., Y. AKYEL, O.N. PAKHOMOVA, B.E. STUCK, AND M.R. MURPHY. 1998. Current state and implications of research on biological effects of millimeter waves: a review of the literature. Bioelectromagnetics 19 (7): 393-413.

PONOMAREV, L., V. DOLGODVOROV, V. POPOV, S. RODIN, AND O. ROMAN. 1996. The effect of low-intensivity electromagnetic microwave field on seed germination. (in Russian). In: Proceedings of Timiryazev Agricultural Academy-2 1996; 42- 46.

RADZEVIČIUS, A., S. SAKALAUSKIENÉ, M. DAGYS, R. SIMNIŠKIS, R. KARKLELIENE, Č. BOBINAS, AND P. DUCHOVSKIS. 2013. The effect of strong microwave electric field radiation on: (1) vegetable seed germination and seedling growth rate. Zemdirbyste-Agriculture 100 (2): 179 184.

RAGHA, L., S. MISHRA, V. RAMACHANDRAN, AND M. S. BHATIA. 2011. Effects of Low-Power Microwave Fields on Seed Germination and Growth Rate. Journal of Electromagnetic Analysis and Applications 3 (5): 165-171.

REDDY, M.B., G.S. V. RAGHAVAN, A.C. KUSHALAPPA, AND T.C. PAULITZ. 1998. Effect of Microwave Treatment on Quality of Wheat Seeds Infected with Fusarium graminearum. Journal of agricultural engineering research 71 (2): 113-117.

REDDY, P., D. J. MYCOCK, AND P. BERJAK 2000. 
The effect of microwave irradiation on the ultrastructure and internal fungi of soybean seed tissues. Seed Science and Technology 28:277-289.

SCIALABBA, A., AND C. TAMBURELLO. 2002. Microwave effects on germination and growth of radish (Raphanus sativus L.) seedlings. Acta Botanica Gallica 149 (2): 113-123.

TKALEC, M., Z. VIDAKOVIC-CIFREK, B. PEVALEK-KOZLINA, K. MALARIC, AND R. MALARIC. 2007. Evaluation of genotoxic potential of microwave electromagnetic field in onion (Allium cepa). In: Electromagnetic Compatibility, 2007.
VELÁZQUEZ-MARTÍ, B., C. GRACIA-LÓPEZ, AND A. MARZAL-DOMENECH. 2006. Germination Inhibition of Undesirable Seed in the Soil using microwave Radiation. Biosystems Engineering 93 (4): 365-373.

WILLIAMS, J.M. 2016. Biological effects of microwaves: Thermal and nonthermal mechanisms. arXiv preprint physics/0102007.

WOO, I..S., I.K. RHEE, AND H.D. PARK. 2000. Differential Damage in Bacterial Cells by Microwave Radiation on the Basis of Cell Wall Structure. Applied and Environmental Microbiology 66 (5): 2243-2247.

\title{
الإرتثاح الإكتروليتي والنمو والإنبات في نبات الثعير المصري الناجم عن اثعة الميكروييف
}

\author{
عبدالغفار (بو السعود'، سمير قاريخ

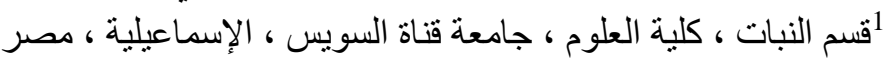

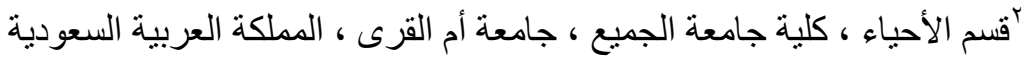 \\ الملخص العربي
}

ادي انتشار الاتصالات وأجزتها الي زيادة التلوث بالأشعة الكهرومغناطيسية خاصة اشعة الميكروويف .لذا تهدف الدر اسة الحالية الي تقييم تأثنير الجر عات المختلفة من أشعة الميكروييف علي مختلف العوامل الفسيولوجية لنبات الشعير. من هذه العوامل الأنبات، النمو، الكلوروفيل و الإرتشاح الإلكتروليتي وموت الخلية. تم تعريض حبوب نبات الشعير جيزة_ه با الي جر عات مختلفة من اشعة الميكروويف معملياً من ا الي . .7 ثانية جر عة تعرض، ونم زراعة النباتات في اطباق بتري مخصصة للزر اعة المعلية علي حبيبات الهيدروجيل. تم تسجيل العديد من العو امل الفسيولوجية للنبات خلال مراحل نمو البادرات الاولي خلال اسبوعين من الزراعة. وقد اوضحت النتائج فى هذه الدراسة الى ان جرعات التعرض المختلفة من نرددات الميكروويف قد احدث بعض

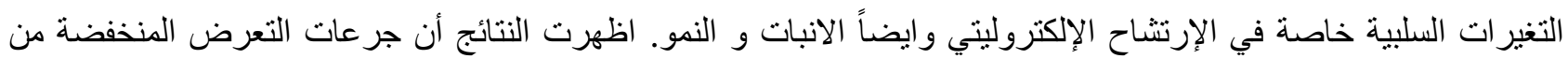
الميكروويف تؤثر ايجابياً على نمو وإنبات نبات الثعير تحت الدراسة، حيث تم تسجيل انبات بنسبة . . 1 ٪ بعد التعرض للميكروييف و علي العكس الجر عات العالية من الميكروويف اثرت سلبياً وادت الي تدني نسب الإنبات و النمو في نبات الشعير تحت الدراسة وزيادة الإرتثاح الإلكتروليتي. تعرض النبات لاشعة الميكروويف بجرعات مختلفة يقلل محتوي النبات من الكلوروفيل

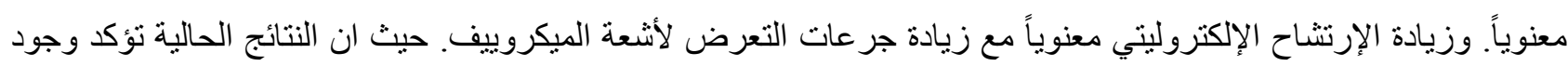

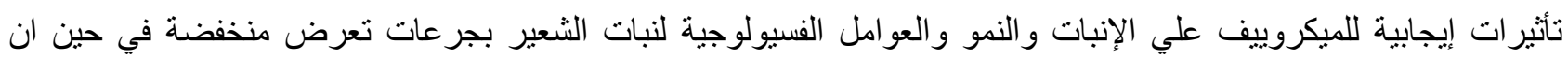
التأثثر ات السلبية تكون لجر عات التعرض العالية. مما يمكن ان يكون له الأثر في تحسين المحاصيل وخصائصها. 